\title{
Perspektif Gender dalam Novel Bekisar Merah Karya Ahmad Tohari: Kajian Sastra Feminis dan Implementasinya dalam Pembelajaran Sastra di SMA
}

\author{
Rita Nilawijaya \\ (corresponding author) \\ Universitas Baturaja, Indonesia \\ Email: nilawijaya.rita@gmail.com \\ Awalludin \\ Universitas Baturaja, Indonesia \\ Email: awalludinawri@gmail.com
}

\begin{abstract}
APA Citation: Nilawijaya, R. \& Awalludin, A. (2021). Perspektif Gender dalam Novel Bekisar Merah Karya Ahmad Tohari: Kajian Sastra Feminis dan Implementasinya dalam Pembelajaran Sastra di SMA. Silampari Bisa: Jurnal Penelitian Pendidikan Bahasa Indonesia, Daerah, dan Asing, 4(2), 291-305. https://doi.org/10.31540/silamparibisa.v4i2.1427
\end{abstract}

\begin{abstract}
Abstrak
Novel memiliki keunikan dalam menceritakan setiap peristiwa kehidupan tokoh utamanya. Begitu juga dalam novel Bekisar Merah Karya Ahmad Tohari berusaha menceritakan tokoh utama perempuan dalam perspektif gender sesuai zamannya. Untuk itu, penelitian ini bertujuan untuk mendeskripsikan: 1) struktur novel Bekisar Merah karya Ahmad Tohari, 2) wujud kesetaraan gender dalam novel Bekisar Merah karya Ahmad Tohari, dan 3) implementasi hasil penelitian novel Bekisar Merah karya Ahmad Tohari dalam pembelajaran sastra di SMA. Data dalam penelitian ini berupa kata, kalimat, ungkapan, dan wacana yang mengandung unsur permasalahan gender dalam novel Bekisar Merah. Teknik cuplikan yang digunakan adalah purposive sampling sedangkan pengumpulan datanya menggunakan teknik dokumentasi dan catat. Uji keabsahan data yang diterapkan yaitu member check dan validasi pakar sastra. Teknik analisis data menggunakan teknik pembacaan model semiotik yang terdiri atas pembacaan heuristik dan hermeneutik. Hasil penelitian memperlihatkan bahwa: 1) struktur novel Bekisar Merah yang didasarkan pada teori fiksi Stanton mengusung tema perjuangan perempuan dalam mewujudkan kesetaraan gender dengan laki-laki. Fakta cerita novel terbagi menjadi tiga, yaitu: tokoh dan penokohan, latar, dan alur cerita. 2) Wujud kesetaraan gender yang terdapat dalam novel adalah: (a) perempuan sebagai mitra sejajar laki-laki, (b) kesamaan kewajiban dan hak antara laki-laki dengan perempuan, dan (c) penentang kekerasan terhadap perempuan. 3) Hasil penelitian diimplementasikan pada skenario pembelajaran dengan KD 7.2 menganalisis unsur-unsur intrinsik dan ekstrinsik novel. Dengan demikian dapat disimpulkan bahwa novel Bekisar Merah karya Ahmad Tohari dapat diimplementasikan dalam pembelajaran sastra di SMA.
\end{abstract}

Kata kunci: perspektif gender, kajian sastra feminis, implementasi dalam pembelajaran sastra 
Rita Nilawijaya, Awalludin

Perspektif Gender dalam Novel Bekisar Merah Karya Ahmad Tohari: Kajian Sastra Feminis dan Implementasinya dalam Pembelajaran Sastra di SMA

\title{
Gender Perspective in the Novel Bekisar Merah by Ahmad Tohari: A Study of Feminist Literature and Its Implementation in Literature Learning in Senior High Schools
}

\begin{abstract}
Novels are unique in telling every event in the life of the main character. Likewise, in the novel Bekisar Merah by Ahmad Tohari, he tries to tell the main female character from a gender perspective according to his era. For this reason, this study aims to describe: 1 ) the structure of the novel Bekisar Merah by Ahmad Tohari, 2) the manifestation of gender equality in the novel Bekisar Merah by Ahmad Tohari, and 3) the implementation of research results in the novel Bekisar Merah by Ahmad Tohari in learning literature in high school. The data in this study are in the form of words, sentences, expressions, and discourses that contain elements of gender issues in the novel Bekisar Merah. The sampling technique used is purposive sampling, while the data collection uses documentation and note-taking techniques. Test the validity of the data applied, namely member check and validation of literary experts. The data analysis technique used a semiotic model reading technique consisting of heuristic and hermeneutic readings. The results of the study show that: 1) the structure of the novel Bekisar Merah, which is based on Stanton's fictional theory, carries the theme of women's struggles in realizing gender equality with men. The facts of the novel are divided into three, namely: characters and characterizations, setting, and storyline. 2) The forms of gender equality contained in the novel are: (a) women as equal partners of men, (b) equal rights and obligations between men and women, and (c) opponents of violence against women. 3) The results of the study were implemented in a learning scenario with KD 7.2 analyzing the intrinsic and extrinsic elements of the novel. Thus, it can be concluded that the novel Bekisar Merah by Ahmad Tohari can be implemented in learning literature in high school.
\end{abstract}

Keywords: gender perspective, feminist literary studies, implementation in literary learning

\section{A. Pendahuluan}

Karya sastra merupakan sebuah struktur yang kompleks, maka untuk memahaminya perlu adanya analisis terhadap bagian-bagian atau unsur-unsurnya (Wahyuningtyas \& Santosa, 2011). Sesungguhnya, analisis itu merupakan salah satu sarana penafsiran atau interpretasi (Pradopo dalam Nilawijaya \& Awalludin, 2021:14). Ilmu sastra merupakan bentuk pengetahuan yang menghadirkan hidup dan kehidupan dalam masyarakat, semua yang dihadirkan dalam peristiwa sastra dapat terjadi dalam kehidupan nyata, dan kehidupan di luar alam nyata. Sastra menyajikan kehidupan yang sebagian besar terdiri dari kenyataan sosial meskipun karya sastra juga meniru alam dan dunia subjektif manusia (Wellek \& Warren, 1990:109). Sosiologi sastra diterapkan dalam penelitian ini karena tujuan dari sosiologi sastra adalah meningkatkan pemahaman karya sastra dalam kaitannya dengan kehidupan masyarakat sehari-hari, menjelaskan bahwa rekaan tidak berlawanan dengan kenyataan dalam hal karya sastra yang dikonstruksikan secara imajinatif, akan tetapi struktur empirisnya dan karya sastra bukan hanya sematamata merupakan wujud gejala individual tetapi merupakan gejala sosial (Nilawijaya \& Inawati, 2020:23). Oleh sebab itu, kegiatan sastra tidak bisa dilepaskan dari unsur masyarakat melalui intuisi sosial yang menggunakan medium bahasa (Awalludin \& Anam, 2019:15).

Silampari Bisa: Jurnal Penelitian Pendidikan Bahasa Indonesia, Daerah, dan Asing Vol. 4, No. 2, 2021 


\section{Rita Nilawijaya, Awalludin}

Perspektif Gender dalam Novel Bekisar Merah Karya Ahmad Tohari: Kajian Sastra Feminis dan Implementasinya dalam Pembelajaran Sastra di SMA

Novel Bekisar Merah karya Ahmad Tohari yang menjadi objek dalam penelitian ini merupakan novel yang berlatar belakang perjuangan seorang perempuan dalam hidupnya dan kebudayaan Jawa dalam masyarakat modern yang menyajikan sebuah gagasan baru tentang rekonstruksi budaya dan sosial yang melahirkan pandangan, sikap, dan gagasan baru mengenai persoalan kemanusiaan. Perjuangan tokoh perempuan dalam novel Bekisar Merah, tampak dalam upaya untuk melawan segenap manifestasi ketidakadilan gender, berupa subordinasi, stereotip, dan kekerasan. Perjuangan yang dilakukan tokoh Lasi berupa argumen spirit persamaan melalui visi novelnya, penolakan kekerasan seksualitas perempuan, serta argumen kebenaran tentang makna perempuan dan laki-laki. Melalui perlawanan tokoh perempuan dalam novel tersebut, dapat dilihat bahwa persoalan dominasi laki-laki atas perempuan bersumber dari persoalan gender, bukan seks.

Beberapa penelitian sebelumnya yang relevan dengan penelitian ini, antara lain penelitian Azizah (2008), Universitas Muhammadiyah Surakarta, melakukan penelitian yang berjudul "Perspektif Jender dalam Novel Perempuan di Titik Nol karya Nawal EL- Saadawi: Tinjauan Sastra Feminis". Hasil analisis menyimpulkan adanya kesetaraan jender dan ketidakadilan jender terhadap perempuan. Kesetaraan jender meliputi perempuan dan pendidikan yang ditunjukkan melalui tokoh Firdaus dan paman. Ketidakadilan jender meliputi (1) kekerasan terhadap perempuan secara fisik yang dialami oleh tokoh Firdaus, (2) beban kerja yang berat ditanggung boleh tokoh Firdaus, (3) streotipe perempuan yang dialami oleh Firdaus, yang tidak diberi kesempatan untuk melanjutkan studi dan diarahkan untuk menikah dengan cara dijodohkan, (4) subordinasi perempuan terjadi pada tokoh Firdaus yang harus menunjukan kepatuhannya pada suaminya.

Selain penelitian tersebut, penelitian relevan lainnya dilakukan oleh Totok (2009), Universitas Muhammadiyah Surakarta, melakukan penelitian yang berjudul "Dimensi Jender Novel Swastika karya Maya Wulan: Tinjauan Sastra Feminis". Penelitian ini menyimpulkan hal-hal: (1) kesetaraan jender, kesetaraan jender yang terkandung dalam novel Swastika meliputi masalah pendidikan dan pelecehan seksual yang dialami oleh sahabat Swastika, yaitu Sila Drupadi, (2) ketidakadilan jender, meliputi (a) tindak kekerasan penculikan, tindak kekerasan dalam novel Swastika dialami oleh Sila, yang diculik diperkosa (b) tindak kekerasan peneroran, Swastika mendapat telephon dari sesorang untuk menghetikan kegiatan seminar, penelephon tersebut mengancam Swastika (c) tindak kekerasan pemerkosaan, pelecehan seksual dialami oleh Sila (d) subordinasi terhadap perempuan, semua keputusan dirumah dipegang penuh oleh Ayah. Ayah mengatur segalanya termasuk sekolah anak-anaknya termasuk Swastika, dan (3) perempuan sebagai objek pelecehan seksual, meliputi pelecehan yang dialami Sila dan pelecehan yang dialami Swastika.

Secara garis besar, teori strukturalisme bisa dibuktikan keilmiahannya dengan tiga hal dasar keilmiahan, yaitu: pertama, sebagai aktivitas yang bersifat intelektual, teori strukturalisme sastra mengarah pada tujuan yang jelas yakni kajian tekstual. Kedua, sebagai metode ilmiah, teori ini memiliki cara kerja teknis dan rangkaian langkah-langkah yang tertib untuk mencapai simpulan yang valid. Ketiga, sebagai pengetahuan, teori strukturalisme sastra dapat dipelajari dan dipahami secara umum dan luas serta dapat dibuktikan kebenaran cara kerjanya secara cermat (Raheliyawati, 2015). 


\section{Rita Nilawijaya, Awalludin}

Perspektif Gender dalam Novel Bekisar Merah Karya Ahmad Tohari: Kajian Sastra Feminis dan Implementasinya dalam Pembelajaran Sastra di SMA

Landasan teori kedua berhubungan dengan kritik sastra feminisme yang tidak dapat dilepaskan dalam pembahasan tentang perspektif gender. Feminisme menurut Ratna (2010:226) berasal dari kata femme, berarti perempuan. Berikutnya, Sugihastuti (2002:18), menjelaskan feminisme sebagai gerakan persamaan antara laki-laki dan perempuan di segala bidang baik politik, ekonomi, pendidikan, sosial dan kegiatan terorganisasi yang mempertahankan hak-hak serta kepentingan perempuan. Feminisme merupakan kesadaran akan penindasan dan pemerasan terhadap perempuan dalam masyarakat, baik di tempat kerja dan rumah tangga.

Kajian gender sebagai landasan yang ketiga dalam penelitian ini. Fakih (2013:7) berpendapat bahwa untuk memahami konsep gender harus dibedakan kata gender dengan kata sex tau jenis kelamin. Secara umum, kata gender digunakan untuk mengidentifikasi perbedaan laki-laki dan perempuan dari segi sosial budaya, maka seks secara umum digunakan untuk mengidentifikasi perbedaan laki-laki dan perempuan dari segi anatomi biologi. Uraian lebih lengkap tentang gender disampaikan oleh Nugroho (2008:19-20) yang menjelaskan bahwa gender sendiri dipahami sebagai sebuah konstruksi sosial tentang relasi laki-laki dan perempuan yang dikonstruksikan oleh sistem keberadaan laki-laki dan perempuan. Dalam kenyataanya konstruksi sosial ini dikonstruksikan oleh kekuasaan, baik kekuasaan politik, ekonomi, sosial, kultural, maupun fisikal karena sebagaimana halnya kenyataan kekuasaan adalah identik dengan kepemimpinan.

Landasan teori keempat yakni nilai pendidikan dalam novel. Nilai pendidikan dapat juga ditemukan dalam novel sebagai sebuah karya sastra. Karya sastra yang diciptakan pengarang merupakan sarana penyampaian amanat kepada pembacanya. Semi (1993:20) mengatakan bahwa nilai didik dalam karya sastra diharapkan dapat memberi solusi atas sebagian masalah dalam kehidupan bermasyarakat. Sastra merupakan alat penting bagi pemikir-pemikir untuk menggerakkan pembaca pada kenyataan dan menolongnya mengambil suatu keputusan apabila ia menghadapi masalah. Adanya nilai pendidikan tersebut dapat digunakan sebagai bahan pembelajaran bagi siswa khususnya dalam penelitian ini adalah siswa pada tingkat pendidikan SMA. Penanaman nilai moral sangat dibutuhkan bagi dunia pendidikan karena nilai moral itu membentuk kepribadian siswa dalam bertindak di lingkungan sosialnya (Zuriah dikutip Nilawijaya \& Inawati, 2020:64). Selanjutnya, dengan membaca karya sastra ini juga dapat mendorong para pembaca menjadi manusia-manusia yang berbudaya (Rahmawati dikutip Awalludin \& Nilawijaya, 2021:34).

Untuk itu, berdasarkan beberapa penelitian relevan dan pentingnya kajian perspektif gender dalam novel Berkisar Merah dari sudut pandang feminimisme, maka dalam penelitian ini bertujuan menjawab tiga rumusan masalah yaitu: 1) Bagaimanakah struktur novel Bekisar Merah karya Ahmad Tohari? 2) Bagaimanakah wujud kesetaraan gender dalam novel Bekisar Merah karya Ahmad Tohari? dan 3) Bagaimanakah implementasi hasil penelitian novel Bekisar Merah karya Ahmad Tohari dalam pembelajaran sastra di SMA. 
Rita Nilawijaya, Awalludin

Perspektif Gender dalam Novel Bekisar Merah Karya Ahmad Tohari: Kajian Sastra Feminis dan Implementasinya dalam Pembelajaran Sastra di SMA

\section{B. Metode Penelitian}

Pendekatan yang digunakan menggunakan pendekatan feminimisme dalam melihat peran dan fungsi perempuan. Metode penelitian yang digunakan dalam penelitian ini adalah metode deskriptif kualitatif dengan strategi penelitian studi kasus terpancang. Peneliti menggunakan teknik penelitian yang bersifat purposive dan teknik analisis datanya menggunakan analisis isi kualitatif. Teknik pengunpulan data dalam penelitian ini menggunakan teknik dokumentasi berupa novel dan teknik catat.

Data dalam penelitian ini berupa kata, kalimat, ungkapan, dan wacana yang mengandung unsur permasalahan gender dalam novel Bekisar Merah karya Ahmad Tohari. Instrumen utama penelitian adalah peneliti sebagai penganalisis yang dibantu dengan dokumen novel dan catatan analisis data penelitian yang bersumber dari novel Berkisar Merah karya Ahmad Tohari.

Uji keabsahan penelitian menggunakan teknik member check dan validasi pakar sastra. Teknik analisis data yang diterapkan yaitu metode pembacaan model semiotik yang terdiri atas pembacaan heuristik dan pembacaan hermeneutik.

Adapun prosedur penelitian yang dilakukan meliputi tahap-tahap, antara lain: (1) mengumpulkan sumber data yang diperlukan, (2) membaca dan memahami sumber data, (3) menganalisis perspektif gender dari sumber data yang berupa novel Berkisar Merah karya Ahmad Tohari, (4) membuat simpulan, dan (5) menyusun laporan penelitian.

\section{Hasil Penelitian dan Pembahasan \\ 1. Hasil Penelitian}

Hasil penelitian dideskripsikan sesuai dengan perumusan masalah dan tujuan penelitian. Di dalam penelitian ini dibahas tentang struktur novel, wujud kesetaraan gender, dan implementasi hasil penelitian terhadap pembelajaran sastra di SMA. Untuk lebih jelasnya, hasil penelitian diuraikan sebagai berikut.

\section{a. Struktur Novel Bekisar Merah Karya Ahmad Tohari}

Struktur novel yang dikaji dalam penelitian ini didasarkan pada teori fiksi Stanton yang terdiri atas tiga bagian yaitu: tema (theme), fakta (fact), dan sarana cerita. Fakta cerita terdiri atas tokoh dan penokohan, latar/ setting, dan alur cerita. Termasuk dalam sarana cerita yaitu judul, sudut pandang, gaya/ tone, simbolisme, dan ironi. Adapun kajian struktur dalam penelitian ini difokuskan pada tema dan fakta cerita.

\section{1) Tema}

Tema merupakan gagasan cerita yang ingin disampaikan pengarang kepada pembaca. Secara keseluruhan, tema yang menjadi dasar adalah perjuangan perempuan dalam mewujudkan kesetaraan gender dengan laki-laki. Hal ini dapat kita lihat pada kutipan-kutipan berikut ini.

"Ke Jakarta atau ke mana saja, aku ikut."

Pardi menggaruk kepala. Sapon malah menjauh lalu duduk menyelonjor di pinggir jalan. la bimbang.

"Bagaimana, Pon?" 


\section{Rita Nilawijaya, Awalludin}

Perspektif Gender dalam Novel Bekisar Merah Karya Ahmad Tohari: Kajian Sastra Feminis dan Implementasinya dalam Pembelajaran Sastra di SMA

"Terserah Mas Pardi. Bagiku, asal kita tidak dituduh macem-macem.

"Mas Pardi ,kata Lasi tiba-tiba, "bumi-langit jadi saksi bahwa aku pergi atas kemauanku sendiri. Ayolah. Atau bila kalian keberatan aku akan turun dan duduk di depan roda. Bagaimana.?"(Tohari, 2013:61).

"Namun dia (Lasi) punya satu kepastian; tak ingin kembali ke Karangsoga, apalagi kembali kepada Darsa. Cukup sudah ketidakramahan orang-orang Karangsoga yang diterimanya sejak bocah. Cukup pula sakit hati akibat kesontoloyoan Darsa. Lasi ingin keluar dari tanah kelahirannya meski di sana masih ada orang yang tak perlu ikut dibenci: Emak, Eyang Mus, bahkan Wiryaji, paman Darsa. Dan Lasi merasa sangat beruntung, dalam ketidak pastiannya berada di Jakarta dapat bertemu dengan orang sebaik $\mathrm{Bu}$ Lanting, yang memberinya pakaian dan tempat berteduh. (Tohari, 2013:109-110)

Selama tiga hari itu Lasi hanya melangkahkan kaki seputar kampung tanpa tujuan tertentu. Selama tiga hari pula Lasi merasakan betapa sikap semua orang Karangsoga jauh berubah. Semua orang ingin memperlihatkan keakraban kepadanya dan wajah mereka cerah ketika diajak bicara. Mata mereka mengatakan, mereka menyesal dan tidak ingin lagi merendahkan Lasi seperti yang terjadi pada masa lalu. (Tohari, 2013:196)

Kutipan-kutipan tersebut menggambarkan tokoh Lasi yang selama ini sebagai perempuan sudah mengerti dengan pemahaman bahwa laki-laki adalah pemimpin bagi mereka. Oleh karena itu, perempuan harus taat pada perkataan laki-laki. Akan tetapi, bila seorang laki-laki melecehkan dan menghianatinya, sebagai perempuan yang mempunyai hati, akan berontak. Pada kutipan tampak bahwa Lasi merasa kecewa atas pengkhianatan Darsa, suaminya ia berselingkuh dengan perempuan lain.

Akhirnya, dengan tekat bulat, ia pergi meninggalkan suami, orang tua, desanya dan orang-orang yang selama ini memandangnya sebelah mata dan keluarganya. Dalam kutipan selanjutnya penjelasan kehidupan Lasi yang sekarang sudah berubah karena di kota Lasi serba kecukupan bahkan menjadi istri konglomerat. Perubahan juga terjadi dari orang-orang kampung yang kagum dan lebih menghormatinya.

\section{2) Fakta Cerita}

Fakta cerita novel Bekisar Merah terbagi menjadi tiga, yaitu: tokoh dan penokohan, latar, dan alur cerita. Tokoh dalam novel terdiri atas Lasi sebagai tokoh utama, Penokohan dilakukan dengan cara analitik dan dramatik dengan menampilkan ciri-ciri fisiologis, psikologis, dan sosiologis (Lubis, dalam Al Ma'ruf, 2010:83). Dimensi fisiologis adalah hal yang berkaitan dengan fisik seseorang. Misalnya usia, tingkat kedewasaan, jenis kelamin, keadaan tubuh, ciri-ciri muka, dan ciri-ciri badan yang lain. Dimensi psikologis adalah dimensi yang berkaitan dengan masalah kejiwaan seseorang, misalnya cita-cita, ambisi, kekecewaan, kecakapan, tempramen, dan sebagainya. Berikutnya adalah dimensi sosiologis yang merupakan ciri-ciri kehidupan masyarakat. Misalnya status sosial, pekerjaan, jabatan, tingkat pendidikan, peranan dalam masyarakat, kehidupan pribadi, pandangan hidup, agama, hobi, dan keturunan.

Latar yang terdapat dalam novel Bekisar Merah meliputi latar tempat yang terdiri atas: Desa Karangsoga, Jakarta, Surabaya, sekolahan, penginapan. Latar 


\title{
Rita Nilawijaya, Awalludin
}

Perspektif Gender dalam Novel Bekisar Merah Karya Ahmad Tohari: Kajian Sastra Feminis dan Implementasinya dalam Pembelajaran Sastra di SMA

waktu yaitu: pagi, siang, sore dan malam hari. Latar sosialnya adalah adanya kebiasaan hidup, tradisi dan budaya. Selanjutnya, amanat yang dapat diambil yaitu keteguhan hati yang tidak mudah menyerah dan ajaran moral untuk bertindak sesuai dengan syariat agama dan semangat meraih cita-cita.

Alur yang digunakan dalam penulisan novel Bekisar Merah ini adalah alur campuran yaitu pengungkapan cerita yang dijalin atas peristiwa yang terjadi pada masa kini dan masa lampau. Uraian alur novel Bekisar Merah ini terdiri atas lima tahap. Pertama merupakan tahap penyituasian diawali dengan pengenalan. Tahap penyituasian adalah tahap yang berisi pelukisan dan pengenalan situasi latar dan tokoh-tokoh cerita. Tahap ini merupakan tahap pembukaan cerita, pemberian informasi awal, dan lain-lain. Tahap penyituasian dalam novel Bekisar Merah digambarkan oleh pengarang adalah sebuah Desa dengan pemandangan yang sangat indah. Hali ini dijelaskan melalui kutipan berikut.

\begin{abstract}
"Pohon-pohon kelapa itu tumbuh di tanah lereng diantara pepohonan yang rapat dan rimbun. Kemiringan lereng membuat pemandangan seberang lembah itu seperti lukisan gaya klasik Bali yang terpapar di dinding langit. Selain pohon kelapa yang memberi kesan lembut, batang sengon yang lurus dan langsing menjadi garis-garis tegak berwarna putih dan kuat. Ada beberapa pohon aren dengan daun mudanya yang mulai mekar; kuning dan segar. (Tohari, 2013:7)
\end{abstract}

\begin{abstract}
"Hujan benar-benar berhenti, bahkan matahari yang kemerahan muncul dari balik awan hitam. Semangat penyadap sejati membangunkan Darsa. la segera bangkit dan keluar dari bilik tidur. Lasi pun mengerti, suaminya terpanggil oleh pekerjaannya, oleh semangat hidupnya. Penderes mana saja akan segera pergi mengangkat pongkor pada kesempatan pertama. Sementara Darsa pergi ke sumur untuk mengguyur seluruh tubuhnya, Lasi menyiapkan perkakas suaminya; arit penyadap pongkor-pongkor dan pikulannya, serta caping bambu (Tohari, 2013:11-12).
\end{abstract}

Kedua, merupakan tahap pemunculan konflik yang bermula Tahap generating, tahap pemunculan konflik, masalah-masalah dan peristiwa-peristiwa yang menyulut terjadinya konflik mulai dimunculkan. Tahap pemunculan konflik dalam novel Bekisar Merah, diawali dari pernikahan yang sudah lama antara Darsa dan Lasi tetapi belum juga diberi momongan.

"Tiga tahun usia perkawinan tanpa anak sering menjadi pertanyaan berat bagi Darsa. Ada teman, meski hanya dalam gurauan, mengatakan Darsa tidak becus sehingga sampai sekian lama Lasi belum juga hamil. Gurauan itu saja sudah sangat menyakitkan hatinya. Apalahi ketika ia menyadari sesuatu yang lebih gawat dan justru lebih mendasar; anak adalah bukti pengejawantahan diri yang amat penting sekaligus menjadi buhul perkawinanya dengan Lasi. Sebagai bukti perkawinan, surat nikah boleh disimpan di bawah tikar. Tapi anak? Bila Lasi sedah membopong bayi, Darsa boleh berharap segala celoteh segera hilang. Kukuh sudah kedaulatan atas Lasi (Tohari, 2013:14).

Ketiga yakni tahap peningkatan konflik. Tahap pemunculan konflik ini ditandai saat Lasi mendengar berita bahwa Darsa (suaminya) terkena musibah jatuh dari pohon kelapa dan kemudian dirawat oleh Bunek. Suatu waktu Bunek mengajak Darsa untuk datang ke rumahnya untuk proses perawatan, akan tetapi Darsa dikabarkan bermain dengan Sipah, anak bungsu Bunek, yang pemalu mengalami 


\section{Rita Nilawijaya, Awalludin}

Perspektif Gender dalam Novel Bekisar Merah Karya Ahmad Tohari: Kajian Sastra Feminis dan Implementasinya dalam Pembelajaran Sastra di SMA

cacat pincang. Kabar berita itu diterima Lasi dari maknya, yaitu Mbok Wiyarji. Hal itu tampak pada kutipan wacana berikut.

"Owalah, Lasi anakku. Kaniaya temen awakmu! Sial amat peruntungan mu!

"Apa, Mak? Sebetulnya ada apa, Mak?

"Gusti. Jadi kamu belum tahu? Darsa, suamimu, tengik! Dia bacin! Dia kurang ajar. Sipah sedang menuntutnya agar dikawin. Kamu tidak usah pulang ke rumahmu. Kamu harus minta cerai." (Tohari, 2013:54)

Keempat ialah tahap klimaks yang merupakan puncak terjadinya konflik. Pada tahap ini dikisahkan Lasi Kabur dari Desanya Karangsoga, karena keputusasaan dan perasaan yang sakit akibat di khianati darsa suaminya. Hal itu tampak pada kutipan wacan berikut.

"Namun dia (lasi) punya satu kepastian; tak ingin kembali ke Karangsoga, apalagi kembali kepada Darsa. Cukup sudah ketidakramahan orang-orang Karangsoga yang diterimanya sejak bocah. Cukup pula sakit hati akibat kesontoloyoan Darsa. Lasi ingin keluar dari tanah kelahirannya meski di sana masih ada orang yang tak perlu ikut dibenci: Emak, Eyang Mus, bahkan Wiryaji, paman Darsa. Dan lasi merasa sangat beruntung, dalam ketidak pastiannya berada di Jakarta dapat bertemu dengan orang sebaik $\mathrm{Bu}$ Lanting, yang memberinya pakaian dan tempat berteduh. (Tohari, 2013:109-110)

Kelima yaitu tahap penyelesaian yang merupakan tahap akhir dari sebuah cerita. Penyelesaian dalam novel ini bersifat tertutup yakni penyelesaian yang ditentukan oleh pengarang.Terlihat dalam kutipan sebagai berikut.

"Jadi sekarang kamu mau apa?" tambah Lasi, sambil tersenyum.

"Secara syariat kita sudah sah menjadi sepasang suami-istri..."

"Begitu, Jat?" potong Lasi

"Ya, betul."

"Betul?" ulang Lasi. “Jadi kamu bersungguh-sungguh dengan perkawinan kita ini?" "Aku sangat bersungguh-sungguh. Dan kamu?

"Entahlah. Tetapi sebelum dipertemukan Eyang Mus, aku menolak lamaran kamu."

"Ya. Dan sekarang kamu masih juga menolak?" "Entahlah. Tetapi, Jat, betulkah aku sekarang itri kamu?" "Betul."

"Jadi sekarang kamu betul-betul suamiku?"

"Ya."

Lasi menangis. Dan terus menangis. Demikian panjang tangis Lasi sehingga Kanjat sempat merasa bingung. Namun kebingungan itu berubah setelah dalam isaknya Lasi berbisik. "Jat, mengapa baru sekarang kita hidup bersama seperti ini?” (Tohari, 2013:312)

Silampari Bisa: Jurnal Penelitian Pendidikan Bahasa Indonesia, Daerah, dan Asing Vol. 4, No. 2, 2021 
Rita Nilawijaya, Awalludin

Perspektif Gender dalam Novel Bekisar Merah Karya Ahmad Tohari: Kajian Sastra Feminis dan Implementasinya dalam Pembelajaran Sastra di SMA

Penyelesaian ini diawali Lasi dengan Kanjat yang akhirnya digambarkan dengan suasana gembira dengan kebersamaan dan kemudian mereka menikah.

\section{b. Wujud Kesetaraan Gender dalam Novel Bekisar Merah Karya Ahmad Tohari}

Wujud kesetaraan gender yang ditemukan didasarkan pada simpulan perjuangan tokoh utama dalam melawan berbagai ketidakadlian gender yang dialami oleh kaum perempuan. Ketidakadilan tersebut yaitu: subordinasi, setereotip, dan kekerasan yang dialami perempuan.

\section{1) Perjuangan Melawan Subordinasi terhadap Perempuan}

Subordinasi perempuan menganggap tidak penting kaum perempuan dan dapat merugikan kaum laki-laki. Hal ini mengakibatkan perempuan tidak bias mengekspresikan dirinya sebagai manusia yang merdeka, untuk beraktivitas dan menggapai masa depan. Anggapan bahwa perempuan itu irrasional atau emosional sehingga perempuan tidak bisa tampil sebagai pemimpin, berakibat munculnya sikap yang menempatkan perempuan pada posisi yang tidak penting.

Subordinasi karena gender tersebut terjadi dalam segala macam bentuk yang berbeda dari tempat ke tempat dan dari waktu ke waktu. Wujud subordinasi perempuan pada novel Bekisar Merah karya Ahmad Tohari tampak pada kutipan berikut.

\footnotetext{
"Ya tak pantas seorang perempuan ikut mengantar barang sampai ke gudang," sambung $\mathrm{Bu}$ Koneng ramah. "Tinggallah sebentar bersama saya. (Tohari, 2013:67)
}

"Aku seorang janda dan usiaku lebih tua. Kamu perjaka, terpelajar dan anak orang ada. Pokoknya aku tak pantas buat kamu. Dan sangat banyak gadis sepadan yang lebih pantas jadi istri kamu." (Tohari, 2013:185)

Kutipan di atas menggambarkan bahwa Lasi yang merupakan perempuan, dilarang ikut seperti laki-laki mengantar barang sampai gudang. Pada kutipan yang kedua, Lasi merasa tidak pantas menjadi pendamping Kanjat karena kondisinya dan beranggapan masih banyak perempuan di luar sana yang lebih pantas dari pada dirinya Oleh karena itu, dapat disimpulkan bahwa wujud kesetaraan gender perempuan dan laki-laki adalah perempuan sebagai mitra sejajar laki-laki.

\section{2) Perjuangan Melawan Stereotip terhadap Perempuan}

Permasalahan gender yang perlu diperjuangkan, salah satunya adalah stereotif perempuan, sebab stereotip perempuan telah melabelkan kaum perempuan dengan anggapan negatif. Stereotip merupakan asumsi yang salah terhadap kaum perempuan, sebab perempuan itu hakikatnya mempunyai peran yang sama tidak hanya mengurusi urusan dapur. Seperti halnya yang tertera pada kutipan berikut.

"Orang Karangsoga sangat mempertimbangkan segi asal-usul dalam hal mencari calon istri atau menantu. Ayah Lasi, meski semua orang Karangsoga tahu siapa 
dia, adalah orang asing yang hanya muncul beberapa bulan di Karangsoga, bahkan sudah lama meninggal, tetapi entah dimana kuburnya. Di Karangsoga, gadis dari keluarga yang tidak utuh kurang disukai. (Tohari, 2013:32)

Kutipan wacana di atas menggambarkan bagaimana Lasi yang berasal dari keluarga tidak lengkap, ayahnya adalah serdadu Jepang, menjadikannya tidak mendapatkan perlakuaan seperti perempuan pada umumnya.

\title{
3) Perjuangan Melawan Kekerasan terhadap Perempuan
}

Kekerasan terhadap kaum perempuan dapat terjadi karena adanya anggapan bahwa perempuan itu lemah sehingga sering dimanfaatkan dari kaum yang merasa berkuasa. Kekerasan emosional dalam novel Bekisar Merah terjadi pada tokoh Lasi saat Darsa suaminya menyeleweng, tidak menghargai dirinya sebagai istri, tampak pada kutipan berikut ini:

... "Lasi kadang merasa ragu dan takut. Namun rasa sakit karena

perbuatan Darsa dan lebih-lebih sakit karena merasa dirinya tidak lagi berharga untuk seorang suami, membuat tekadnya lebih pekat, lari dan mbalelo. Adalah satu-satunya cara untuk melampiaskan perlawanan sekaligus membela keberadaannya. Lari dan lari meski Lasi sadar tak punya tempat untuk dituju."( Tohari, 2013:61)

"Lasi memang menangis. Kini ia mulai sadar akan apa yang sedang dilakukannya; lari meninggalkan Karangsoga, bumi yang melahirkan dan ditinggalinya selama dua puluh empat tahun usianya. Lari dari rumah; rumah lahir, rumah batin tempat dirinya hadir, punya peran dan punya makna. (Bekisar Merah, 2013:61)

Kekerasan gender yang dialami Lasi juga tampak pada kutipan berikut.

\begin{abstract}
... "tetapi malam itu Handarbeni tak memberi janji apa-apa melainkan sebuah tawaran yang membuat Lasi merasa terpojok, bahkan terhina."Las aku memang sudah tua. Aku tak lagi bisa memberi dengan cukup. Maka, bila kamu kehendaki, kamu aku ijinkan meminta kepada lelaki lain, dan syaratnya hanya satu: kamu jaga mulut dan tetep tinggal disini menjadi istriku."... (Tohari, 2013:192)
\end{abstract}

Peneliti menyimpulkan, berdasarkan pembahasan di atas, wujud kesetaraan gender dalam hal ini adalah perlunya sikap saling menghargai antara laki-laki dan perempuan. Sikap tersebut, terutama adalah menghargai perasaan perempuan dan tidak menganggap bahwa martabat kaum perempuan lebih rendah daripada kaum laki-laki.

\section{c. Implementasi Hasil Penelitian dalam Pembelajaran Sastra di SMA}

Wujud kesetaraan gender yang terdapat dalam novel Bekisar Merah dapat diimplementasikan sebagai materi ajar pembelajaran sastra di SMA. Hal tersebut dapat diterapkan pada Standar Kompetensi Keterampilan Membaca, semester 1. Adapun Standar Kompetensi 7.1 memahami berbagai hikayat, novel Indonesia/novel terjemahan. Kopetensi Dasar 7.2 menganalisis unsur-unsur intrinsik hikayat. Materi pembelajaran difokuskan pada aspek-aspek gender 
yang terdapat dalam novel Bekisar Merah karya Ahmad Tohari dan tata cara menyampaikan pendapat dengan santun, baik, dan benar.

Indikator pencapaian kompetensi yang diinginkan yaitu: (1) Mampu mengidentifikasi unsur-unsur intrinsik dan ekstrinsik novel Indonesia dan terjemahan, (2) Mampu menganalisis unsur-unsur intrinsik (alur, tema, penokohan, sudut pandang, latar, dan amanat) dan ekstrinsik novel Indonsia, dan (3) Mampu membandingkan unsur-unsur intrinsik dan ekstrinsik novel Indonesia dengan novel terjemahan.

Pembelajaran dijadwal dalam dua pertemuan. Adapun pada pertemuan pertama, kegiatan yang ditekankan yaitu siswa dilatih berargumen secara santun, mendengar dan menghargai pendapat orang lain, membangun kesepakatan, dan menyimpulkan bersama melalui kegiatan yang bersifat kooperatif. Selain itu, siswa juga diberi tugas untuk membaca novel berjudul Bekisar Merah karya Ahmad Tohari, guna mengetahui unsur intrinsik novel, aspek-aspek ketidakadilan gender dan perjuangan tokoh utama dalam mewujudkan kesetaraan gender yang terdapat di dalamnya dengan menuliskan kutipan-kutipan novel yang berkaitan dengan hal tersebut. Tugas dikerjakan secara berkelopok di luar jam pelajaran.

Pembelajaran pertemuan kedua dilanjutkan dengan presentasi dan diskusi hasil dari tugas yang telah dikerjakan siswa. Penekanan kegiatan pembelajaran adalah pada penyimpulan wujud kesetaraan gender yang terdapat dalam novel Bekisar Merah. Selain itu, dengan dibimbing oleh guru, siswa juga dapat mencermati dan mengambil teladan yang baik dari hal-hal yang disampaikan dalam diskusi.

\section{Pembahasan}

\section{a. Struktur Novel Bekisar Merah Karya Ahmad Tohari}

Berdasarkan hasil penelitian dan teori yang digunakan menunjukkan bahwa di dalam novel Berkisar Merah karya Ahmad Tohari terdapat struktur karya sastra yang difokuskan pada tema dan fakta cerita. Tema merupakan gagasan cerita yang ingin disampaikan pengarang kepada pembaca. Secara keseluruhan, tema yang menjadi dasar adalah perjuangan perempuan dalam mewujudkan kesetaraan gender dengan laki-laki. Dalam novel ini Lasi akhirnya pergi meninggalkan suami, orang tua, desanya dan orang-orang yang selama ini memandangnya sebelah mata dan keluarganya sehingga mengubah kehidupan Lasi yang sekarang sudah berubah karena di kota Lasi serba kecukupan bahkan menjadi istri konglomerat. Perubahan juga terjadi dari orang-orang kampung yang kagum dan lebih menghormatinya.

Fakta cerita yang ditemukan dalam novel Bekisar Merah karya Ahmad Tohari ini diklasifikasikan mmenjadi tiga bagian, yaitu: tokoh dan penokohan, latar, dan alur cerita. Tokoh dalam novel terdiri atas Lasi sebagai tokoh utama, Penokohan dilakukan dengan cara analitik dan dramatik dengan menampilkan ciri-ciri fisiologis, psikologis, dan sosiologis. Dimensi fisiologis adalah hal yang berkaitan dengan fisik seseorang. Misalnya usia, tingkat kedewasaan, jenis kelamin, keadaan tubuh, ciriciri muka, dan ciri-ciri badan yang lain. Dimensi psikologis adalah dimensi yang berkaitan dengan masalah kejiwaan seseorang, misalnya cita-cita, ambisi, kekecewaan, kecakapan, tempramen, dan sebagainya. Berikutnya adalah dimensi sosiologis yang merupakan ciri-ciri kehidupan masyarakat. Misalnya status sosial, 
pekerjaan, jabatan, tingkat pendidikan, peranan dalam masyarakat, kehidupan pribadi, pandangan hidup, agama, hobi, dan keturunan.

Hal ini sejalan dengan teori Sugihastuti (2002) dan mendukung hasil penelitian yang pernah dilakukan oleh Awalludin \& Nilawijaya (2021) dan Raheliyawati (2015) yang juga menemukan struktur novel seperti tema dan fakta cerita yang terdapat dalam novel yang dianalisis. Artinya, hasil penelitian ini sejalan dengan teori yang digunakan dan penelitian relevan yang digunakan, karena di dalam penelitian ini sama-sama ditemukan struktur novel seperti tema dan fakta cerita.

\section{b. Wujud Kesetaraan Gender pada Novel Bekisar Merah Karya Ahmad Tohari}

Hasil penelitian terhadap wujud kesetaraan gender yang ditemukan dalam penelitian ini didasarkan pada simpulan perjuangan tokoh utama dalam melawan berbagai ketidakadilan gender yang dialami oleh kaum perempuan yang terdapat dalam novel tersebut. Ketidakadilan tersebut berkaitan dengan subordinasi, setereotip, dan kekerasan yang dialami tokoh perempuan dalam novel tersebut. Hal ini ditunjukkan oleh tokoh perempuan tersebut melalui perjuangan melawan subordinasi terhadap perempuan, perjuangan melawan stereotip terhadap perempuan, dan perjuangan melawan kekerasan terhadap perempuan yang terjadi dalam cerita yang dikisahkan dalam novel tersebut. Hal ini sejalan dengan teori Mansour (2013) dan hasil penelitian yang pernah dilakukan oleh Azizah (2008) dan Totok (2009) yang juga menemukan wujud kesetaraan gender dalam novel yang mereka analisis.

\section{c. Implementasi Hasil Penelitian dalam Pembelajaran Sastra di SMA}

Berdasarkan hasil penelitian menunjukkan bahwa hasil penelitian ini dapat diimplementasikan pada skenario pembelajaran novel yang merujuk pada aspek Pembelajaran Membaca. Hal ini dapat diimplementasikan pada Standar Kompetensi 7.1 memahami berbagai hikayat, novel Indonesia/novel terjemahan. Kopetensi Dasar 7.2 menganalisis unsur-unsur intrinsik hikayat. Implementasi hasil penelitian pada pembelajaran sastra dalam penelitian ini didasarkan pada kurikulum KTSP mata pelajaran Bahasa Indonesia untuk siswa SMA kelas XI semester I. Materi pembelajaran dapat difokuskan pada aspek-aspek gender yang terdapat dalam sebuah novel. Adapun Indikator pencapaian kompetensi yang diinginkan adalah (1) mampu mengidentifikasi unsur-unsur intrinsik dan ekstrinsik novel Indonesia dan terjemahan, (2) mampu menganalisis unsur-unsur instrinsik (alur, tema, penokohan, sudut pandang, latar, dan amanat) dan ekstrinsik novel Indonesia, dan (3) mampu membandingkan unsur-unsur intrinsik dan ekstrinsik novel Indonesia dengan novel terjemahan.

\section{Simpulan} berikut.

Berdasarkan hasil penelitian dan pembahasan dapat diambil simpulan sebagai

1. Struktur Novel Bekisar Merah Karya Ahmad Tohari

Struktur novel Bekisar Merah dalam penelitian ini difokuskan pada kajian tema dan fakta cerita. Tema yang diusung dalam cerita novel tersebut adalah perjuangan perempuan dalam mewujudkan kesetaraan gender dengan laki-laki. Adapun fakta cerita novel terbagi menjadi tiga, yaitu: tokoh dan penokohan, latar,

Silampari Bisa: Jurnal Penelitian Pendidikan Bahasa Indonesia, Daerah, dan Asing Vol. 4, No. 2, 2021 


\section{Rita Nilawijaya, Awalludin}

Perspektif Gender dalam Novel Bekisar Merah Karya Ahmad Tohari: Kajian Sastra Feminis dan Implementasinya dalam Pembelajaran Sastra di SMA

dan alur cerita. Tokoh dalam novel terdiri atas Lasi sebagai tokoh utama, Darsa, Bu Koneng, Bu Lanting, Kanjat, Eyang Mus, Wiryaji, mbok Wiryaji Pardi, dan Sapon. Penokohan dilakukan dengan cara analitik dan dramatik dengan menampilkan ciriciri fisiologis, psikologis, dan sosiologis.

Berikutnya, latar yang terdapat dalam novel Bekisar Merah meliputi latar tempat yang terdiri atas: Desa Karangsoga, Jakarta, Surabaya, penginapan. Latar waktu yaitu: pagi, siang, sore dan malam hari. Latar sosialnya adalah adanya kebiasaan hidup, tradisi dan budaya. Selanjutnya, alur yang digunakan dalam penulisan novel Bekisar Merah adalah campuran. Amanat yang dapat diambil yaitu keteguhan hati yang tidak mudah menyerah dan ajaran moral untuk bertindak sesuai dengan syariat agama dan semangat meraih cita-cita.

2. Wujud Kesetaraan Gender yang Terdapat pada Novel Bekisar Merah Karya Ahmad Tohari

Wujud kesetaraan gender yang dapat disimpulkan yaitu: pertama, perempuan sebagai mitra sejajar laki-laki lebih tepatnya adalah sebagai pembimbing dan mitra sejajar, sehingga perempuan juga memiliki kekuatan untuk menjadi pemimpin. Kedua, kesamaan porsi (kewajiban maupun hak) antara laki-laki dengan perempuan di dalam kehidupan. Ketiga, tentangan terhadap kekerasan yang kerap dialami perempuan baik itu emosional maupun kekerasan fisik.

\section{Implementasi Hasil Penelitian dalam Pembelajaran Sastra di SMA}

Implementasi hasil penelitian diaplikasikan pada skenario pembelajaran novel Bekisar Merah dengan merujuk pada Aspek Pembelajaran Membaca. Adapun Standar Kompetensi 7.1 memahami berbagai hikayat, novel Indonesia/ novel terjemahan. Kopetensi Dasar 7.2 menganalisis unsur-unsur intrinsik hikayat. Implementasi hasil penelitian pada pembelajaran sastra dalam penelitian ini didasarkan pada kurikulum KTSP mata pelajaran Bahasa Indonesia untuk siswa SMA kelas XI semester 1. Materi pembelajaran difokuskan pada aspek-aspek gender yang terdapat dalam novel Bekisar Merah karya Ahmad Tohari dan tata cara menyampaikan pendapat dengan santun, baik, dan benar. Indikator pencapaian kompetensi yang diinginkan adalah (1) mampu mengidentifikasi unsurunsur intrinsik dan ekstrinsik novel Indonesia dan terjemahan; (2) mampu menganalisis unsur-unsur instrinsik (alur, tema, penokohan, sudut pandang, latar, dan amanat) dan ekstrinsik novel Indonesia; dan (3) mampu membandingkan unsur-unsur intrinsik dan ekstrinsik novel Indonesia dengan novel terjemahan. 


\section{Rita Nilawijaya, Awalludin}

Perspektif Gender dalam Novel Bekisar Merah Karya Ahmad Tohari: Kajian Sastra Feminis dan Implementasinya dalam Pembelajaran Sastra di SMA

\section{Daftar Pustaka}

Awalludin, A., \& Anam, S. (2019). Stratifikasi Sosial dalam Novel Pabrik Karya Putu Wijaya. Silampari Bisa: Jurnal Penelitian Pendidikan Bahasa Indonesia, Daerah, dan Asing, 2(1), 15-28. doi:10.31540/silamparibisa.v2i1.276

Awalludin, A., \& Nilawijaya, R (2021). Sikap Tokoh dalam Novel Burung-Burung Cahaya Karya Jusuf AN: Sebuah Analisis Psikologi Sastra. Diksa : Pendidikan Bahasa dan Sastra Indonesia, 7(1), 33-41 https://doi.org/10.33369/diksa.v7i1.10405

Azizah, L. (2008). Perspektif Jender dalam Novel Perempuan di Titik Nol Karya Nawal EL-Saadawi: Tinjauan Sastra Feminis. Skripsi: Universitas Muhammadiyah Surakarta.

Fakih, M. (2013). Analisis Gender dan Transformasi Sosial. Yogyakarta: Pustaka Pelajar.

Nilawijaya, R., \& Awalludin, A. (2021). Tinjauan Sosiologi Sastra dalam Novel Hafalan Shalat Delisa Karya Tere Liye dan Relevansinya terhadap Pembelajaran Sastra di SMA. Silampari Bisa: Jurnal Penelitian Pendidikan Bahasa Indonesia, Daerah, dan Asing, 4(1), 13-24. doi:10.31540/silamparibisa.v4i1.1212

Nilawijaya, R., \& Inawati, I. (2020). Resepsi Mahasiswa Universitas Baturaja terhadap Nilai Moral Tokoh Utama dalam Novel Ayat-Ayat Cinta Karya Habiburrahman El Shirazy. Lentera: Jurnal IImiah Kependidikan, 13(1), 63-78. http://jurnal.stkippgribl.ac.id/index.php/lentera/article/view/504

Nilawijaya, R., \& Inawati, I. (2020). Tinjauan Sosiologi Sastra Novel Ayah Karya Andrea Hirata dan Implementasinya sebagai Bahan Ajar Sastra di SMA. Jurnal Ilmiah Bina Bahasa, 13(02), 23-32. https://doi.org/10.33557/binabahasa.v13i02.1173

Nugroho, R. (2008). Gender dan Strategi Pengarus Utamanya di Indonesia. Yogyakarta: Pustaka Design.

Raheliyawati, E. (2015). Substansi dan Cara Kerja Teori Strukturalisme. http://ellyraheliyawati-fib13.web.unair.ac.id/artikel. Diunduh pada tanggal 26 Desember 2016.

Ratna, N. K. (2010). Teori, Metode, dan Teknik Penelitian Sastra. Yogyakarta: Pustaka Pelajar. 
Rita Nilawijaya, Awalludin

Perspektif Gender dalam Novel Bekisar Merah Karya Ahmad Tohari: Kajian Sastra Feminis dan Implementasinya dalam Pembelajaran Sastra di SMA

Semi, M.A. (1993). Metode Penelitian Sastra. Bandung: Angkasa.

Sugihastuti, S. (2002). Kritik SastraFeminis: Teori dan Aplikasinya. Yogyakarta: Pustaka Pelajar.

Tohari, A. (2013). Berkisar Merah. Jakarta: Gramedia Pustaka Utama.

Totok, S. (2009). Dimensi Jender Novel Swastika karya Maya Wulan Tinjauan: Sastra Feminis. Skripsi: Universitas Muhammadiyah Surakarta.

Wahyuningtyas, S., \& Santosa, W.H. (2011). Sastra: Teori dan Implementasi. Surakarta: Yuna Pustaka.

Wellek, R., \& Warren, A. 1990. Teori Kesusastraan. Terjemahan Melani Budianta. Jakarta: Gramedia.

Silampari Bisa: Jurnal Penelitian Pendidikan Bahasa Indonesia, Daerah, dan Asing Vol. 4, No. 2, 2021 